\title{
迷路誘導型バランスボードによる動的バランス学習
}

\section{Learning Effect of Dynamic Balance in a Labyrinth-guiding Balance Board Test}

\author{
岩月 順子1) 岩月 宏泰2) 喜多 弘美3) \\ 林幸子4) 長谷川 美幸5)
}

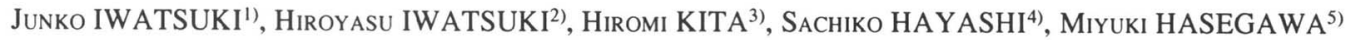

${ }^{1)}$ Department of Rehabilitation, Tokai Memorial Hospital: 681-47 Ohbara, Hazawa-cho, Kasugai-city, Aichi, 487 Japan. $T E L+81$ 568-88-0568.

${ }^{2}$ Department of Physical Therapy, Nagoya University College of Medical Technology

${ }^{3)}$ Department of Rehabilitation, Mitsubishi Nagoya Hospital

${ }^{4)}$ Devision of Physical Therapy, Nagoya Memorial Hospital

${ }^{5)}$ Devision of Physical Therapy, Kojima Hospital

J. Exerc. Physoil. 9(2): 97-100, 1994. Submitted July 30, 1993. Accepted April 28, 1994.

ABSTRACT: For the purpose of evaluating the effectiveness of a simple instability board apparatus of DYBOC developed by Nakayama et al., we prepared a labyrinth-guiding balance board and examined the standard values and learning effect. Eight healthy young adults performed 10 measurements, and the required time to finish a labyrinth and the locus of center of gravity for $15 \mathrm{sec}$ were recorded. Both the required time and sway distance showed no correlation with body height and weight, and a negative correlation, though non significant, was observed between the required time and sway distance. During 10 consecutive measurements, there were significant variations both in the required time $(F=2.78, p<0.05)$ and sway distance $(\mathrm{F}=3.52, \mathrm{p}<0.05)$. The required time showed a tendency to decrease until the 5 th measurements, and was subsequently unchanged showing approximately 23 sec. It was concluded that learning effect of a labyrinthguiding balance board becomes plateau in 5 measurements with the shorter required time to solve of approximately $23 \mathrm{sec}$.

Key words: balance board, healthy young adult, dynamic balance, locus of center of gravity

要旨 中山らが紹介したDYBOCのうち, 迷路誘導型バランスボードを自作し所要時間と重心軌跡から 標準値と学習効果について検討した。

対象は健常青年者 8 名であった。結果； (1)初回測定値とパラメーターとの関連では重心動摇距離, 所要時間とも身長，体重と相関を認めず，両測定値間に有意ではないが負の相関を認めた。(2)連続 10 回の各測定値の変動では重心動摇距離 $(\mathrm{F}=3.52, \mathrm{p}<0.05)$, 所要時間 $(\mathrm{F}=2.78, \mathrm{p}<0.05)$ と全試行を通 して変動を認めた。(3)所要時間は初回から 5 回までは減少傾向を示したが, それ以降は約 23 秒と値に 変動を認めなかった。

以上の結果から, 健常青年者における本機器に対する慣れは 5 回で plateauに達し, 約 23 秒が限界 であることが認められた。

キーワード：バランスボード, 健常青年者, 動的バランス, 重心軌跡

1)東海記念病院:春日井市廻間町大洞681-47 (广 487) TEL 0568-88-0568.

2)名古屋大学医療技術短期大学部 3) 三菱名古屋病院 4)名古屋記念病院 5)小嶋病院

受付日 1993年8月 8日 受理日 1994年4月28日 


\section{I 緒 言}

ヒトの直立姿勢は視覚, 前庭感覚, 抗重力筋固 有感覚, 足底皮膚感覚などを入力とする多くの反 射により制御されている1)。直立位から構えや体 位を変化させる際には各反射機構が中枢で統御さ れ，全身の筋緊張を高め身体の重心線が支持面か ら逸脱しないよう働く。

我々は以前より動作時の刻々と変化する状況 に対応するバランス能力を定量的に評価したいと 考えていたが良い方法を見つけることができな かった。しかし，中山ら 2-4)が紹介している DYBOC (Dynamic body control training \& evaluation machine) のうち簡易不安定板機器が動的バラ ンスを評価する上で適しているのではないかと期 待した。しかし, 本機器を用いて詳細に検討した 報告は現在のところ見あたらず今後の研究成果を 期待するところである。今回, 我々は簡易不安定 機器の有用性を評価する目的で迷路盤誘導型バラ ンスボードを製作し標準值と学習効果について検 討した。

\section{II 対象と方法}

対象は健常青年者 8 名（男性 2 名, 女性 6 名) であった。被験者の身長は $163.3 \pm 6.7 \mathrm{~cm}$, 体重は
$54.3 \pm 7.2 \mathrm{~kg}$ であった。

迷路誘導型バランスボード: 本機器は直径 30 $\mathrm{cm}$ の半球型バランスボードの前方に高さ $50 \mathrm{~cm}$ の ところに迷路盤を取り付けたものを製作した。 ボード上の被験者が身体を傾けると傾いた方向へ 迷路内の玉が転がる装置である（図１）, 被験者は ボード上で足底内側がボード中央から $4 \mathrm{~cm}$ ずつ 離し並行になるように立たせた。その後, 合図と 同時に迷路内スタート時点の玉を動かし始め素早 くゴールまで誘導する課題を行わせた。なお本機 器は重心動摇計 (三栄測器 SG06) 上に設置し, 終 了までの所要時間と開始から 15 秒間の重心軌跡 を測定した。測定は 10 回連続して行い, 各試行 間隔は 30 秒間とし, 測定中は検者が後方に立ち 転倒の予防に努めた。統計学的処理には分散分析 と相関係数を用い, 危険率 $5 \%$ 未満を有意差あり と判定した。

\section{III 結 果}

1. 初回測定值とパラメーターとの関連

重心動摇距離, 所要時間とも身長, 体重と相関 を認めず，両測定值間に有意ではないが負の相関 を認めた（表 1 )。

2. 連続 10 回の各測定値の変動（図 2 )

重心動摇距離は全試行を通して有意な変動を 認めた $(F=3.52, p<0.05)$ 。初回から 7 回目まで減

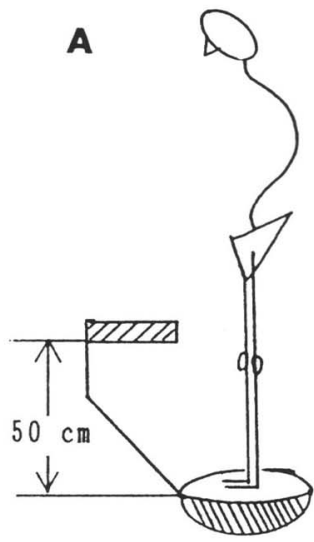

B

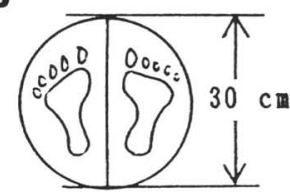

C

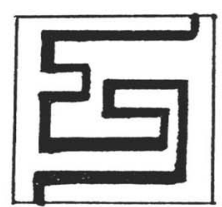

図1 測定方法

$\mathrm{A}$ ：測定の実際 B：足部の位置 $\mathrm{C}$ ：迷路盤 
少する傾向を示したが, それ以降は初回値より増 加していく傾向を認めた。所要時間は重心動摇距 離と同様に全試行を通して変動を認め $(\mathrm{F}=2.78$, $\mathrm{p}<0.05$ ), 初回から 5 回までは減少傾向を示した が, それ以降は值に変動を認めなかった。

\section{IV 考 察}

立位平衡能に関する研究では平衡神経学, 体育 学など種々の分野から行われている。研究に用い られる計測方法には身体各部の偏位の計測や足部 の荷重状態から重心の偏位を分析するものがあ る。後者の方法は臨床で広く用いられているが,

表 1 相関マトリックス

\begin{tabular}{lccc}
\hline & 身長 & 体重 & 所要時間 \\
\hline 重心動摇距離 & 0.24 & 0.22 & -0.45 \\
所 要 時 間 & 0.36 & 0.28 & - \\
\hline
\end{tabular}

静止立位における重心偏位の解析に留まってい る。しかし, 日常生活でなす諸動作は重心の垂直 投影点が支持基底面に必ずしも含まれていること は少ない。そのため動的バランスについて定量的 な解析が望まれる。そこで我々は迷路誘導型バラ ンスボードを製作して, 所要時間, 開始から 15 秒間の重心軌跡を測定し, 他のパラメーターとの 関連と学習効果を検討した。その結果, 各測定値 間で負の相関を認めた。このことは所要時間が短 い者ほどバランスボード上での動摇が大きいこと を意味する。迷路盤の玉を素早く誘導するために は, 体幹や下肢の関節, 筋群を協調させて盤を左 右, 前後に傾斜させていく必要がある。初回の所 要時間が短い者では動的バランスが優れていると 考えられる。

一方, 本検査の学習効果について, 所要時間は 5 回まで減少していく傾向を認めたが, それ以降 は約 23 秒と殆ど変化がみられなかった。それに 対して重心動摇距離は 7 回以降初回値より増加し
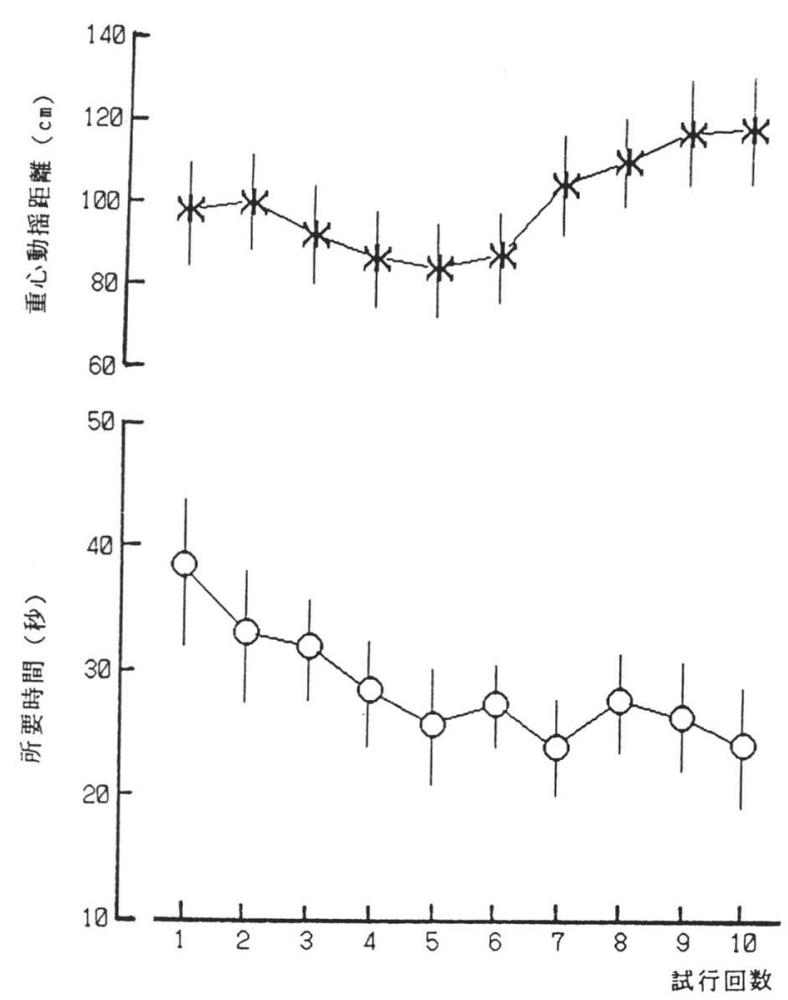

図210 回試行時の重心動摇距離, 所要時間の変化 Mean \pm SD 
ていく傾向を認めた。重心動摇距離の増加は本機 器に慣れてきたため, バランスボードの傾斜を被 験者が耐えうる限界まで行うことができたものと 推測される。しかし, 重心動摇距離が増加しても 所要時間が短縮しなかったことから，5回の試行 で限界に達したことが考えられる。

本機器は持ち運びが容易であり,ゲーム感覚で 動的バランスを所要時間から評価できるため, フィールド検査としても有用性があると考えられ る。今後の課題として年代別, 性別の比較, 他の 動的バランス能を示す指標との関連性および臨床 応用が考えられる。

\section{引用文献}

1) 福田 精: 運動と平衡の反射生理. 第 2 版, 医学書 院, 1981 .

2) 中山彰一・他：下肢障害に対する動的関節制動訓練. 理学療法学, 13: 27-40, 1986.

3) 石橋敏郎·他: 下肢制動能の訓練·評価機器の開発. 九スポ学会誌, 4: 145-149, 1992.

4) 中山彰一・他：下肢関節障害に対する “Proprioceptive”訓練. 総合リハ, 13: 705-712, 1985. 